$34 \mathrm{~m}$

c. 72.1

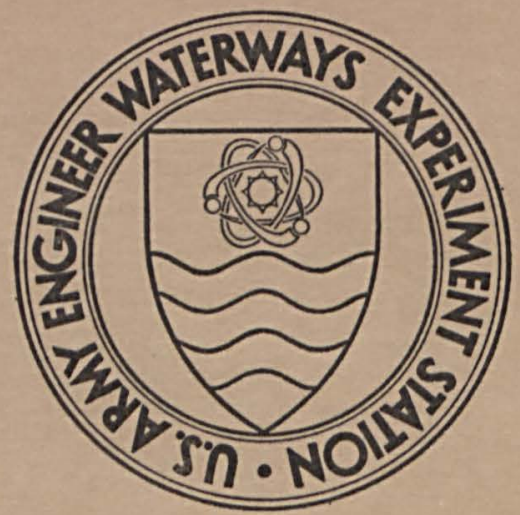

MISCELLANEOUS PAPER C-72-I

\title{
POROSITY-STRENGTH CONSIDERATIONS FOR CELLULAR CONCRETE
}

by

G. C. Heff

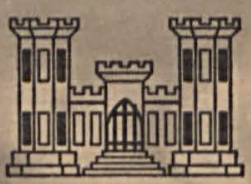

US ARMY ENGINEER WATERWAYS EXPERIMENT STATION VICKSBURG, MISSISSIPPI

April 1972

Conducted by U. S. Army Engineer Waterways Experiment Station, Vicksburg, Mississippi 


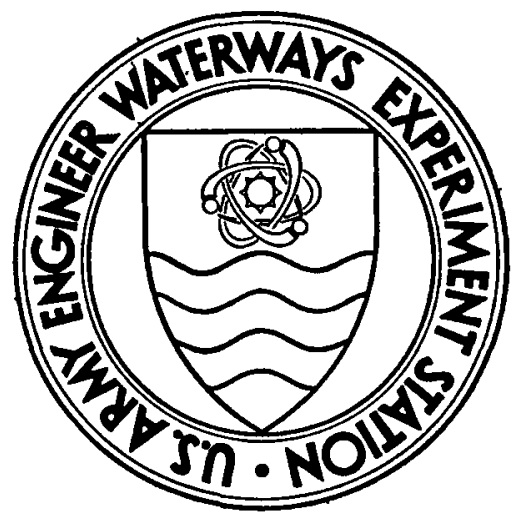

MISCELLANEOUS PAPER C-72-I

\section{POROSITY-STRENGTH CONSIDERATIONS FOR CELLULAR CONCRETE}

by

G. C. Hoff

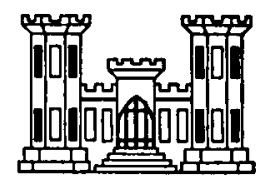

April 1972

Conducted by U. S. Army Engineer Waterways Experiment Station, Vicksburg, Mississippi 


\section{FOREWORD}

This paper was initially prepared at the request of Highway Research Board Subcomittee A2E06 on Basic Research Pertaining to Portland Cement and Concrete and was presented but not published as one of six papers at a meeting of that committee held at the 50th Annual Highway Research Board Meeting in Washington, D. C., on 21 January 1971. A subsequent request was made by the Cement and Concrete Research Journal that the manuscript be submitted for publication consideration in that Journal. The manuscript was reviewed and cleared for publication at the Office, Chief of Engineers.

The many studies which provided the information and data discussed herein were conducted by the U. S. Axmy Engineer Waterways Experiment Station (WES), Vicksburg, Mississippi, under the sponsorships of the Defense Nuclear Agency; Air Force Weapons Laboratory; Air Force Office of Civil Engineering; Space and Missile System Organization, U. S. Air Force Systems Command; Armed Services Explosives Safety Board; and Sandia Corporation. The work was accomplished during the period from 1961 to 1971 under the general supervision of Mr. T. B. Kennedy, former Chief, and Mr. Bryant Mather, present Chief, of the WES Concrete Division, and Mr. J. M. Polatty, Chief, Engineering Mechanics Branch. Mr. George C. Hoff was the Project Officer for the majority of the work discussed and prepared this paper. Directors of the WES during the conduct of these investigations and the preparation of this paper were COL Alex G. Sutton, Jr., CE; COL John R. Oswalt, Jr., CE; COL Levi A. Brown, CE; and COL Ernest D. Peixotto, CE. Technical Directors were Mr. J. B. Tiffany and Mr. Fred R. Brown. 
POROSITY-STRENGTH CONSIDERATIONS FOR CELLULAR CONCRETE*

\author{
George C. Hoff \\ Concrete Division \\ U. S. Army Engineer Waterways Experiment Station \\ V1cksburg, Mississippi
}

ABSTRACT

The inclusion of air voids in the determination of total porosity for neat cellular concretes permits the determination of a single strengthporosity relation for a given cement. This relation can be expressed in terms of water-cement ratio and density, thus providing a simple tool for the design of these concretes.

RÉSUMÉ

L'inclusion des pores d'air dans la determination de la porosite totale pour les bétons cellulaires purs nous permet de déterminer une seule rclation résistance/porosité pour un ciment donné. Cetté relation peut être exprimée en fonction du rapport $\frac{E}{C}$ et de la densité; ainsi elle nous donne un instrument simple pour le calcul de ces bétons.

* Presented at the Conference Session on Basic Research on Portland Cement and Concrete, 50th Annual Meeting of the Highway Research Board, Washington, D.C. January 1971. 


\section{Introduction}

Cellular concrete is generally defined as a lightweight product consisting of portland cement, cement-silica, cement-pozzolan, lime-pozzolan or lime-silica pastes, or pastes containing blends of these ingredients and having a homogeneous void or cell structure attained with gas-forming chemicals or foaming agents (1). Air contents from 30 to 80 percent are not uncommon. When the binder consists of other than just portland cement, autoclave curing is usually employed and the conclusions reached in this paper do not apply.

\section{Porosity-Strength Considerations}

The cellular concretes discussed in this paper were made using only portland cement, water, and a preformed foam which provided the air contents. They can be represented by the simple model shown in Fig. 1 as being composed of air, evaporable water, nonevaporable water, and cement. Porosity, $n$, is defined as the fractional portion of the total volume that is air plus evaporable water. As such, cellular concrete can be considered as a cement paste with a large vold content or high porosity. The inclusion of evaporable water as a vold space is not unreasonable even in concrete that is not dry when tested because the large void contents of these concretes and the slow rates of compressive loading normally used allow sufficient moisture movement to alleviate pore pressure buildup which could contribute to load resistance.

The strength of cement paste at any water-cement ratio is a function of the chemical composition of the cement, the entrained and entrapped air contents, age of the paste, fineness of the cement, and temperature and humidity of curing. Ideally, the strength can be expressed as:

$$
\sigma=f\left(\sigma_{0}, n, m\right) \ldots
$$

where $\sigma_{0}=$ theoretical paste strength at zero porosity,

$\mathbf{n}=$ porosity, and

$\mathrm{m}$ = maturity factor.

The influences of all the above factors except composition and air contents can be represented by the maturity factor, $m$, which is a measure of the fraction of cement which has become hydrated; hence, $0 \leq m \leq 1$. That is to say that when the paste is freshly mixed, $m=0$, and as the above factors contribute to the hydration of the cement, $m$ increases to $m=1$ which indicates that all hydration is complete. The theoretical paste strength, $\sigma_{0}$, is never actually achieved in practice, but is determined by extrapolation from experimental data. For a paste that has completed all possible hydration $(\mathrm{m}=1)$, 


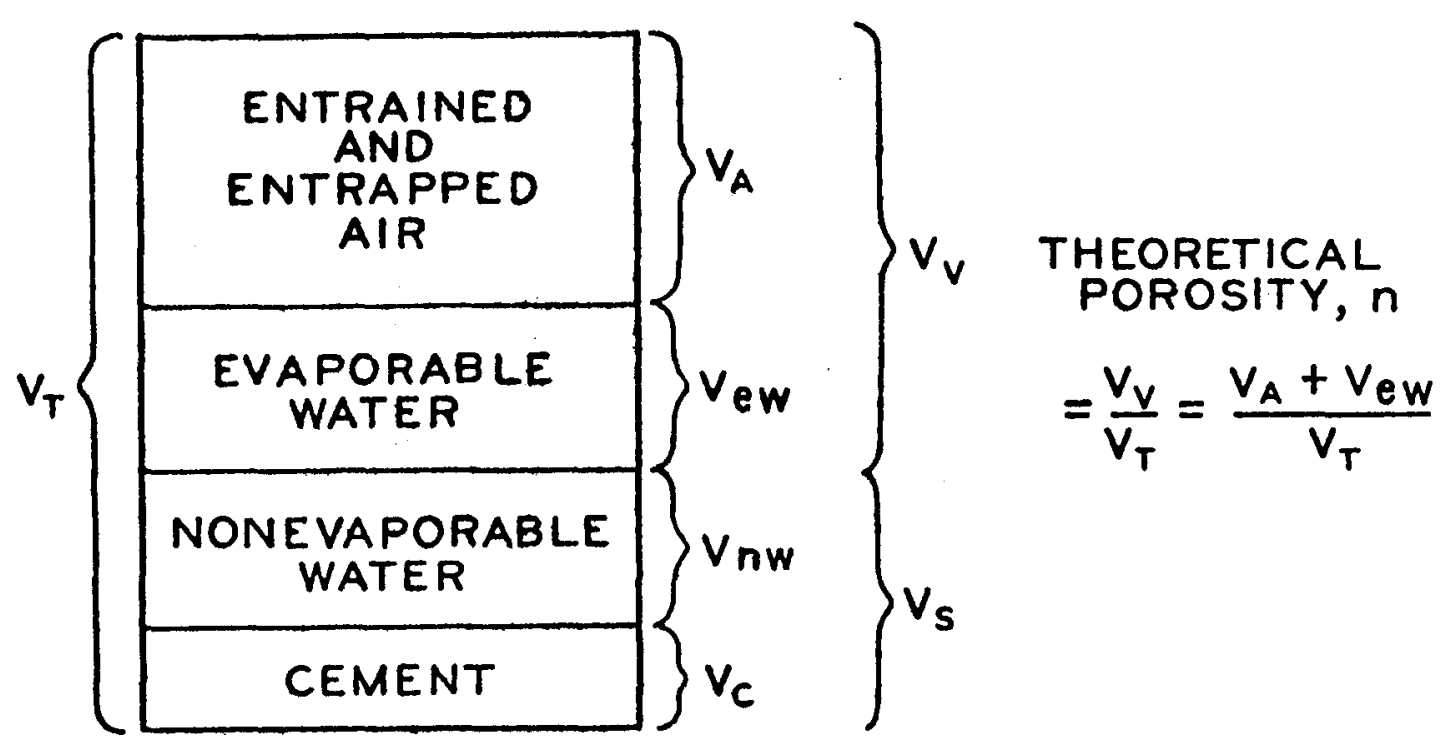

\section{FIG. I. CELLULAR CONCRETE MODEL}

$\sigma_{0}$ is principally a function of the chemical composition of the cement. The porosity as defined previously includes both the entrained and entrapped air plus the capillary porosity. The capillary porosity increases with increasing amounts of mixing water, that is, with water-cement ratio, and decreases with increasing hydration or maturity of a paste. When $m=1$, the porosity becomes a constant and the strength of the paste is only a function of that porcsit; and the theoretical paste strength.

Under ideal curing conditions, the hydration of cement in test cylinders has been shown to continue for long perlods of time (2), thus making actual determinations of $\sigma_{0}$ and $n$ when $m=1$ unrealistic. From practical considerations, it is reasonable to redefine the full maturity $(\mathrm{m}=1)$ to be that amount of hydration that has occurred at a prescribed time after casting, subject to the constraints of a specified curing history; for example, $m=1$ at 28 days with water curing at $73 \mathrm{~F}$. The following derivations assume that $m=1$. Then:

$$
\sigma=f\left(\sigma_{0}, n\right) \ldots
$$

Numerous Investigators have related the strength of hardened cement paste to porosity either directly or indirectly. Powers and Brownyard (3) found that:

$$
\mathrm{S}=827.4 \quad \frac{\mathrm{v}_{\mathrm{m}}}{\mathrm{w}_{\mathrm{o}}}-24.8 \quad \ldots
$$

where $S$ = strength of the hardened paste and

$V_{n}=$ the constant in the BET surface area equation. 
$V_{m}$ is proportional to the surface area of the cement gel, which in turn is proportional to the amount of cement gel. $W_{0}$ is the original water content after bleeding. Powers later suggested $(4,5)$ that the strength of the hardened paste could be empirically related to a volume of gel/space ratio by a power function where:

$$
s=s_{o}(x)^{b}
$$

where $X=$ gel/space ratio and could include the effects of entrained and entrapped air (5) and $b$ varied somewhat but was approximately equal to three.

Wischers (6) found from experimental evidence that:

$$
\mathrm{s}=\mathrm{s}_{\mathrm{o}}\left(1-\mathrm{v}_{\mathrm{p}}\right)^{2.7}
$$

where $V_{p}$ is the porosity. Based on a simple geometric model, Hansen (7) suggested that:

$$
\mathrm{s}=\mathrm{s}_{\mathrm{o}}\left(1-1.2 \mathrm{v}_{\mathrm{p}}^{2 / 3}\right)
$$

Auskern (8) suggested that Powers and Brownyard's data for strength be plotted against $\left(W_{0}-W_{n}\right)=W_{e}$, i.e., the original water content less the nonevaporable water content, where $W_{e}$ is more closely related to porosity than $\mathrm{V}_{\mathrm{m}} / \mathrm{W}_{\mathrm{o}}$. Auskern then found that:

$$
S=\left(1-w_{e}\right)^{6}
$$

and further speculated that the strength of hardened cement paste-could be approximated as:

$$
s=s_{0}\left(1-v_{p}\right)^{6}
$$

In all of the above cases, it is readily obvious that a decrease In porosity will reflect an increase in the strength of the paste. For cellular-concrete design purposes, a suggested approach is then to relate the desired strength to the porosity of the cellular concrete which in turn is a function of the watercement ratio, concrete density, and specific gravity of the cement. This will provide some latitude in the selection of a cellular-concrete design for a particular requirement.

From the model shown in Fig. 1, the volume of water, $V_{w}$, in the concrete will be considered as being composed of both evaporable and nonevaporable water (9), that is:

where

$$
v_{w}=v_{e w}+v_{n w} \quad \cdots
$$

$$
\begin{aligned}
& v_{\text {ew }}=\text { volume of evaporable water } \\
& v_{n w}=\text { volume of nonevaporable water }
\end{aligned}
$$


The space left in the concrete after the evaporable water leaves is considered as vold space. The theoretical porosity, $n$, for a neat cellular concrete, as defined above, is then:

$$
\begin{aligned}
\mathbf{n} & =\frac{\mathrm{v}_{\mathrm{v}}}{\mathrm{v}_{\mathrm{t}}} \\
& =\frac{\mathrm{v}_{\mathrm{a}}+\mathrm{v}_{\mathrm{ew}}}{\mathrm{v}_{\mathrm{c}}+\mathrm{v}_{\mathrm{w}}+\mathrm{v}_{\mathrm{a}}} \\
& =\frac{\mathrm{v}_{\mathrm{v}}}{\mathrm{v}_{\mathrm{c}}+\mathrm{v}_{\mathrm{nw}}+\mathrm{v}_{\mathrm{v}}}
\end{aligned} \ldots
$$

where

$$
\begin{aligned}
& v_{v}=\text { volume of volds } \\
& v_{t}=\text { total volume } \\
& v_{a}=\text { volume of air } \\
& v_{c}=\text { volume of cement }
\end{aligned}
$$

The density expression:

$$
d_{c}=\frac{w_{t}}{v_{t}}=\frac{w_{c}+w_{w}}{v_{c}+v_{w}+v_{a}} \quad \ldots
$$

where

$$
\begin{aligned}
& d_{c}=\text { concrete density, pcf } \\
& w_{t}=\text { total weight } \\
& w_{c}=\text { weight of cement } \\
& w_{w}=\text { welght of water }
\end{aligned}
$$

can be rewritten in terms of water-cement ratio and specific gravities to be:

$$
\begin{aligned}
d_{c} & =\frac{(1+k) w_{c}}{v_{c}+v_{n w}+v_{v}} \\
& =\frac{(1+k) v_{c} \rho_{c} \gamma_{w}}{v_{c}+v_{n w}+v_{v}}
\end{aligned}
$$

where

$$
\begin{aligned}
& k=\text { water-cement ratio (by weight) }=W_{w} / W_{c} \\
& \rho_{c}=\text { specific gravity of the cement } \\
& \gamma_{w}=\text { unit weight of water. } \\
& \text { The volume of voids is then expressed as: }
\end{aligned}
$$$$
v_{v}=\frac{1}{d_{c}}\left[(1+k) v_{c} \rho_{c} \gamma_{w}-d_{c}\left(v_{c}+v_{n w}\right)\right] \ldots
$$

Using an average value of 0.20 for the ratio of hydration water to cement by weight (9): 


$$
\frac{w_{n w}}{w_{c}}=0.20=\frac{\left(\gamma_{w}\right) V_{n w}}{\rho_{c} \gamma_{w} V_{c}}
$$

or

$$
\mathrm{v}_{\mathrm{nw}}=0.20 \rho_{\mathrm{c}} \mathrm{v}_{\mathrm{c}}
$$

Equation 16 can then be written as:

$$
\begin{aligned}
v_{v} & =\frac{1}{d_{c}}\left[(1+k) v_{c} \rho_{c} \gamma_{w}-d_{c}\left(v_{c}+0.20 \rho_{c} v_{c}\right)\right] \ldots \\
& =\frac{v_{c}}{d_{c}}\left[(1+k) \rho_{c} \gamma_{w}-d_{c}\left(1+0.20 \rho_{c}\right)\right] \quad \ldots
\end{aligned}
$$

Substituting in Equation 10,

$$
\begin{aligned}
\mathbf{n} & =\frac{v_{c}}{d_{c}} \frac{\left[(1+k) \rho_{c} \gamma_{w}-d_{c}\left(1+0.20 \rho_{c}\right)\right]}{\left(w_{t} / d_{c}\right)} \\
& =v_{c} \frac{\left[(1+k) \rho_{c} \gamma_{w}-d_{c}\left(1+0.20 \rho_{c}\right)\right]}{(1+k) w_{c}} \\
& =v_{c} \frac{\left[(1+k) \rho_{c} \gamma_{w}-d_{c}\left(1+0.20 \rho_{c}\right)\right]}{v_{c}(1+k) \rho_{c} \gamma_{w}} \\
\mathbf{n} & =1-\frac{d_{c}\left(1+0.20 \rho_{c}\right)}{(1+k) \rho_{c} \gamma_{w}}
\end{aligned}
$$

Equation 24 is the expression for the theoretical porosity of the celiuiar concrete in terms of density, water-cement ratio of the freshly mixed concrete, specific gravity of the cement, and the unit weight of water. It has been assumed in this development that the specific gravity of water is unity.

The work by other investigators (3-8) suggests that Equation 2 be expressed in the form:

$$
\sigma=\sigma_{0}(1-n)^{b}
$$

where $b$ is a power exponent. Combining Equations 24 and 25 , the strength of a cellular concrete can be expressed as a function of two easily determined variables of water-cement ratio and density plus the spectfic gravity of the cement, where

$$
\sigma_{y}=\sigma_{0}\left[\frac{d_{c}\left(1+0.20 \rho_{c}\right)}{(1+k) \rho_{c} \gamma_{w}}\right]^{b}
$$

or

$$
\sigma_{y}=\sigma_{0}\left(\frac{d_{c}}{1+k}\right)^{b}\left(\frac{1+0.20 \rho_{c}}{\rho_{c} \gamma_{w}}\right)^{b}
$$




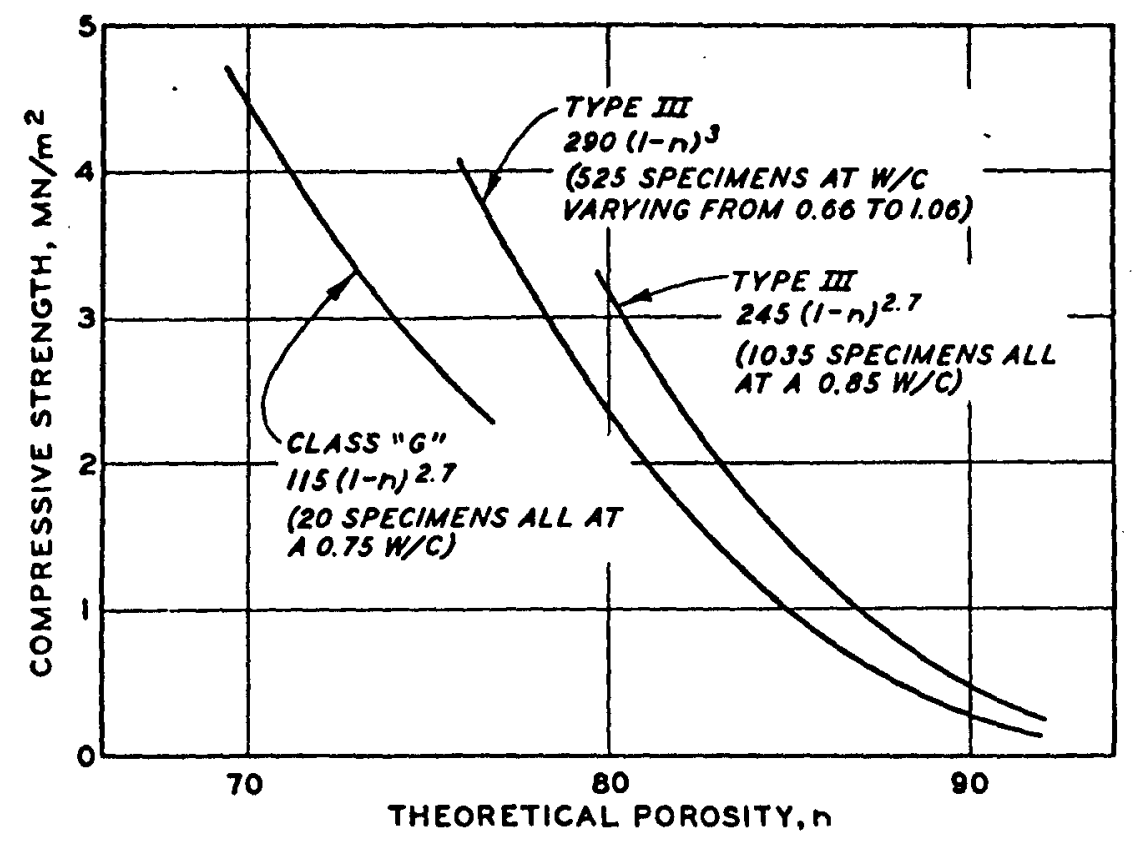

FIG. 2. STRENGTH-POROSITY RELATIONS

\section{Experimenta1}

To check the usefulness of equation 27, the data from two previous studies $(10,11)$ using two different type III cements and some unpublished data Involving a class "G" ofl well cement were employed. The results are shown in F1g. 2. All specimens were bag-cured from the time of placing and were evaluated at Lô days aye. Wátei-zement ratles (by weight) varled from 0.66 to 1.06 . Concrete densities in the as-cast condition at 28 days varied from 320 to $1000 \mathrm{~kg} / \mathrm{m}^{3}$. The specific gravity of all three cements was 3.15 .

For the data of the 525 specimen group, representing one of the type III cements (10), separate regression analyses for individual specimen groups having water-cement ratios of $0.66,0.76,0.86,0.96$, and 1.06 indicated that the line-of-best-fit for each data group was indeed of the form of Equation 25 but that the coefficients. $\sigma_{0}$ and $b$ varied somewhat between each watercement ratio. Correlation coefficients varied between 0.94 and 0.98 . Statistically, however, the lines-of-best-fit for each water-cement ratio were not significantly different from each other; hence, all data were grouped together and analyzed with the resulting coefficients of $\sigma_{0}=290 \mathrm{NN} / \mathrm{m}^{2}$ and $b=3$ and a correlation coefficient of 0.94 .

The 1035 specimens made with the other type III cement (11) all had the same intial water-cement ratio of 0.85 . The analysis produced coefficients 
of $\sigma_{0}=245 \mathrm{MN} / \mathrm{m}^{2}$ and $b=2.7$ with a correlation coefficient of 0.95 . The limited number of class $G$ cement specimens produced coefficients of $\sigma_{0}=115 \mathrm{MN} / \mathrm{m}^{2}$ and $b=2.7$ with a correlation coefficient of 0.94 .

\section{Discussion of Results}

The use of Equation 27 with cellular-concrete strength data appears to be satisfactory. The exponent $b$ varied from 2.7 to 3 , which was within the realm of those observed by other Investigators $(5,6)$ of hardened cement paste. The coefficlent $\sigma_{0}$ for the type III cements was within the range of values that have often been suggested for zero porosity hardened portland-cement pastes. The coefficient $\sigma_{0}$ for the class " $G$ " cement was quite low at $115 \mathrm{MN} / \mathrm{m}^{2}$. This cement was very coarse, having a Blaine fineness of only $2980 \mathrm{~cm}^{2} / \mathrm{g}$ as opposed to the 4500 and $4650 \mathrm{~cm}^{2} / \mathrm{g}$ fineness of the type III cements. Because of the reduced amount of initial surface area, the amount of class "G" cement hydrated at 28 days would have been considerably less than that of the type III cements, and because the amount of cement gel formed is a function of the strength developed, the value of $\sigma_{0}=115 \mathrm{MN} / \mathrm{m}^{2}$ appears to be reasonable.

Other cements may produce slightly different results. A posstble approach to a more universal relationship for all cements is to rewrite Equation 27 in the form:

$$
\frac{\sigma_{y}}{\sigma_{0}}=\left(\frac{d_{c}}{1+k}\right)^{b}\left(\frac{1+0.20 \rho_{c}}{\rho_{c} \gamma_{w}}\right)^{b} \quad \cdots
$$

Reasonable limits of specific gravity for portland cements are from 3.1 to 3.2 . The last term in Equation 28 varies then between $(0.000524)^{b}$ and $(0.000513)^{b}$, respectively. Assuming the value of $b$ to be of the same order and magnitudes as indicated in Fig. 2, the specific gravity term can be assumed to be fairly constant for the practical range of specific gravities, and hence

$$
\frac{\sigma_{y}}{\sigma_{0}}\left(\frac{d_{c}}{1+k}\right)^{b}
$$

The effect of pore size on strength has not been considered in Equation 24. The same porosity can be achieved for many small voids or for fewer larger volds. The air bubble structures of the concretes discussed in this paper were similar because the same foaming agent was used in making all the concrete. Comparisons between cellular concretes made with the same cement but with three different commercially available (in the USA) foaming agents showed no significant differences in strength for a given density and water-cement ratio even though the mean air bubble size varied slightly. This indicated that from 
practical considerations, the problem of pore size may be minor.

The use of Equations 27 or 28 in the design of neat cellular concretes on a strength basis for varying job conditions has utility and greatly simplifies the design when the cellular concrete is continually made with the same cement over considerable time periods such that the effort involved in determination of $\sigma_{0}$ and $b$ is minimized. In other instances, reasonable assumptions of $\sigma_{0}$ and $b$ can provide a starting point in establishing the densities and water-cement ratios that might be required. The ranges of densities and watercement ratios used in this study are not necessarily the limits of design that can be used to satisfy cellular-concrete strength requirements. From practical considerations, however, the lower limit of density is approximately $280 \mathrm{~kg} / \mathrm{m}^{3}$. It is also doubtful that water-cement ratios below 0.50 could be used without creating fabrication problems. The upper limits of density with respect to Equation 27 have not been established. Densities of $1120 \mathrm{~kg} / \mathrm{m}^{3}$ have been used with good success. Water-cement ratios above 1.1 (by weight) begin to create fabrication problems because of the excess of free water especially when coarse cements are used.

\section{Conclusions}

In the design of cellular concretes, the use of the space occupied by evaporable water plus the air void space as the total void space in the concrete permits the determination of a single strength-porosity relation for a given cement. From weight-volume considerations, this relation can be expressed in terms of water-cement ratio and concrete density as shown in Equation 27, thus providing a simple approach to the design of neat cellular concretes on a strength basis. The possibility of a universal design relation for most cements also exists.

\section{$\underline{\text { References }}$}

1. ACI Committee 116, "Cement and Concrete Terminology," Publication SP-19, p 24 (19.67).

2. Bryant Mather, "Stronger Concrete," Highway Research Record 210, HRB, pp 1-28 (1967).

3. T. C. Powers and T. L. Brownyard, "Studies of the Physical Properties of Hardened Portland Cement Paste," J. Am. Conc. Inst. (Proc.) 43, pp 101-132, 249-336, 469-504, 549-602, 669-712, 815-880, 933-992 (1947).

4. T. C. Powers, "The Physical Structure and Engineering Properties of Concrete," PCA Bulletin 90 (1958). 
5. T. C. Powers, "The Nonevaporable Water Content of Hardened Portland-Cement Paste--Its Significance for Concrete Research and Its Method of Determination," ASTM Bulletin 158, pp 68-76 (1949).

6. G. Wischers, "Einfluss einer Temperäturanderung auf die Festigkeit von Zementstein und Zementmörtel mit Zuschlag-Stoffen Verschiedener Wärmedehnung," Schriftenreihe der Zementindustrie Verein Deutscher Zementwerke E.V., Duisseldorf, p 50 (1961).

7. T. C. Hansen, "Cracking and Fracture of Concrete and Cement Paste," ACI Publication SP-20, pp 43-66 (1968).

8. A. Auskern, "A Model for the Strength of Cement-Polymer and ConcretePolymer Systems," Brookhaven Nat1. Lab., BNL-1349312-2 (1969).

9. M. Polivka, J. W. Kelly, and C. H. Best, "A Physical Method for Determining the Composition of Hardened Concrete," ASTM STP-205, pp 135-152 (1958).

10. G. C. Hoff, "Shock-Absorbing Materials, Report 2, Cellular Concrete as a Backpacking Material," TR 6-763, USAEWES, Vicksburg, Miss. (1971).

11. G. C. Hoff, R. L. Stowe, and W. L. Burnett, "Operation Flintlock, Shot Pile Driver, Grouting and Materials Contro1," MP C-69-7, USAEWES, Vicksburg, Miss. (1969). 
Unclassified

Security Cleselfication

DOCUMENT CONTROL DATA - R \& D

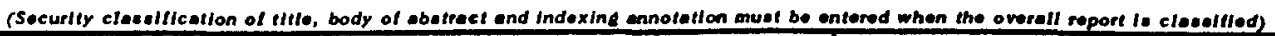
1. OAIGINA TING AC TIVITY (Comoralo evehor)

U. S. Army Engineer Waterways Experiment Station

Vicksburg, Miss.

20. REPONT BECURITY CLABSIFICATION

Unclassified

J. KEFONT TITLE

POROSITY-STRENGTH CONSIDERATIONS FOR CELLULAR CONCRETE

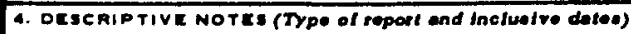

Final report

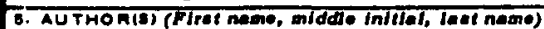

George C. Hoff

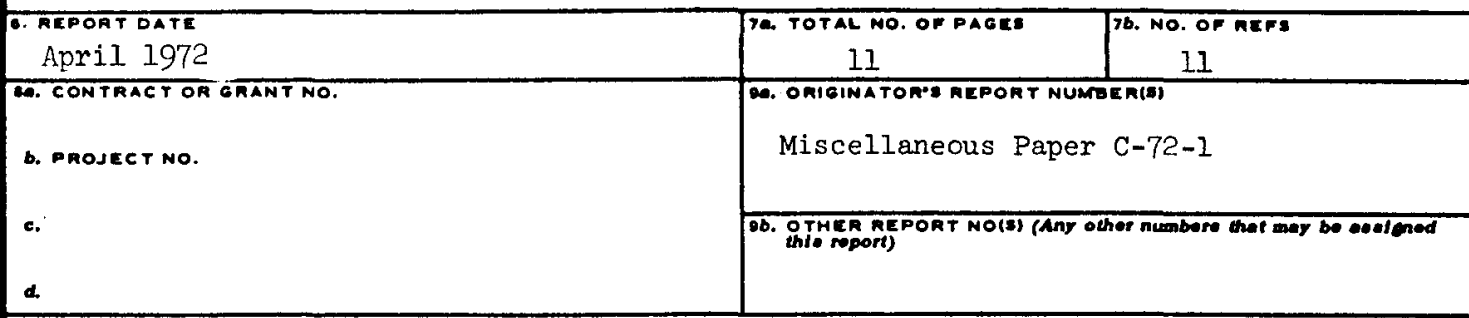

10. DISTRIBUTION ITATEMENT

Approved for public release; distribution unlimited.

\begin{tabular}{|l|l|}
\hline 11. SUPPLEMENTARY NOTES & 12. BPONSOMING MILITARY ACTIVITY \\
\hline
\end{tabular}

\section{AOSTRACT}

The inclusion of air voids in the determination of total porosity for neat cellular concretes permits the determination of a single strength-porosity relation for a given cement. This relation can be expressed in terms of water-cement ratio and density, thus providing a simple tool for the design of these concretes. 


$$
[]
$$

